\title{
High lake levels on Alxa Plateau during the Late Quaternary
}

\author{
WANG NaiAng, LI ZhuoLun*, CHENG HongYi, LI Yu \& HUANG YinZhou \\ College of Earth and Environmental Sciences, Center for Hydrologic Cycle and Water Resources in Arid Region, Lanzhou University, Lanzhou \\ 730000, China
}

Received December 6, 2010; accepted March 25, 2011; published online May 10, 2011

\begin{abstract}
Field investigations including lake shoreline measurement and ${ }^{14} \mathrm{C}$ chronology have been carried out on the Alxa Plateau to better understand the formation and evolution of the high lake levels in northwest China during the late Pleistocene. Comprehensive field investigations show that there are at least ten shorelines at different elevations at Juyan Lake, at least four on the northwest side of the Jilantai Salt Lake, and nine shorelines and one terrace on the northeast margin of Zhuye Lake. Stratigraphic correlations and chronological evidence indicate that the paleo-lakes have the highest lake levels in Marine Isotope Stage (MIS) 3. Though the optically stimulated luminescence (OSL) results which have been reported by some scholars do not support this view, the fact that the paleo-lakes have the highest lake levels in MIS 3 can not be denied. Differences between OSL and ${ }^{14} \mathrm{C}$ results from this work might indicate that high lake levels existed on the Alxa Plateau during two different periods. It also suggests that the high lake levels may exist in both MIS 5 and early MIS 3. This paper also provides the basic hydrological information for further water resources research in this arid region.
\end{abstract}

Alxa Plateau, desert, MIS 3, MIS 5, high lake levels, late Quaternary

Citation: $\quad$ Wang N A, Li Z L, Cheng H Y, et al. High lake levels on Alxa Plateau during the Late Quaternary. Chinese Sci Bull, 2011, 56: 1799-1808, doi: $10.1007 / \mathrm{s} 11434-011-4498-8$

Many studies have reported high lake levels in different regions of China during the Late Quaternary; for example, the Hexi Corridor and Alxa Plateau [1-7], Xinjiang [8,9], and the Qinghai-Tibet Plateau [10-19]. These studies prove that lake levels were at their highest in northwest China during the late Pleistocene. It not only provides important evidence for Pleistocene environmental changes, but also informs research on modern anthropogenic climate change and its mechanism(s).

There is debate regarding the chronology of high lake levels in northwest China during the late Quaternary. Using ${ }^{14} \mathrm{C}$ dating, on the Qinghai-Tibet Plateau, it appears that the highest lake levels existed between 40 and $25 \mathrm{ka} \mathrm{BP}$ (Unless otherwise stated, all ${ }^{14} \mathrm{C}$ dating results are uncorrected, and the time unit used is ka BP. Where a different dating method is used, the time unit used is ka), with some until $20 \mathrm{ka} \mathrm{BP}$ [14]. This evidence is the basis of the existence of high lake levels in MIS 3. But Zhao et al. [16] used U-series dating to

\footnotetext{
*Corresponding author (email: lizhuolunlzl@163.com)
}

suggest that high lake levels in Nam Co and the adjacent regions formed during the Last Interglacial (MIS 5). Madsen et al. [10] employing the optically stimulated luminescence (OSL) method, considered that the Qinghai Lake's highest level occurred in MIS 5, and furthermore, high stands in MIS 3 have not been discovered, and may not have existed at all, or may have been at or below postglacial highs. Rhode et al. [17] also support this view from their OSL results at the Qinghai Lake. However, other work using OSL support the view that high stands existed both in MIS 5 and MIS $3[18,19]$. So, it seems that the ${ }^{14} \mathrm{C}$ and OSL data are inconsistent with each other in northwest China.

Stratigraphic correlations and chronological evidence derived from ${ }^{14} \mathrm{C}$ indicate that the paleo-lakes started to develop around $42 \mathrm{ka} \mathrm{BP}$ to $37 \mathrm{ka} \mathrm{BP}$, with the highest lake levels formed around $35 \mathrm{ka} \mathrm{BP}$, and were maintained until about $22 \mathrm{ka} \mathrm{BP}[4,6] .{ }^{14} \mathrm{C}$ results of the highest terrace of the eastern end of the Juyan Lake (located in the northwest Badan Jaran Desert) indicate that the lake levels were maximal about 33 ka BP [20]. In terms of when peak lake levels 
occurred, the results of these studies $[4,6,20]$ are consistent with those of $\mathrm{Li}$ [14]. But in the Ulan Buh Desert, OSL data show that maximal Jilantai lake level occurred at least 50$60 \mathrm{ka}$ ago.

It remains to be seen to what degree the temporal variation of peak lake levels varied regionally [21], and whether peak lake levels occurred on the Alxa Plateau during the MIS 3. Both MIS 3 and MIS 5 were relatively humid [22-26], and furthermore, during early and late MIS 3, the climate conditions were similar to each other [27]. This would imply that the climate conditions in MIS 3 were suitable for the formation of high lake levels. This paper examines whether high lake levels were high in the Hexi Corridor and Alxa Plateau during MIS 3, and furthermore, it differentiates the periods of high lake levels between MIS 3 and MIS 5.

\section{Study area}

The Alxa Plateau lies between the Chinese border and the Hexi Corridor, with an elevation of 1000-1500 m above sea level (ASL) being higher in the south than the north. It covers an area of approximately $300000 \mathrm{~km}^{2}$, to the west are the Mazong Mountain, and to the east the Helan Mountain (Figure 1). On the plateau, few mountains are higher than $2000 \mathrm{~m}$, and the lowest area is near Juyan Lake, with an elevation of $820 \mathrm{~m}$. There are some arid denudations on the Plateau that are around 100-200 m high, and they divide the Plateau into many inland basins. The landscape of the plateau is desert and desert steppe, moving dunes. The plateau comprises the Badain Jaran Desert, the Tengger Desert, the
Ulan Buh Desert and other deserts. Among these, the Badain Jaran Desert and Tengger Desert are located along two sides of the Yabulai Mountain, which are oriented northeast to southwest. The annual precipitation is $50-150 \mathrm{~mm}$, which decreases from southeast to northwest. The sources for the Shiyang and Heihe Rivers are the Qilian Mountain to the south. Both of the inland rivers have terminal lakesZhuye Lake and Juyan Lake [28,29].

\subsection{Zhuye Lake}

The Zhuye Lake is the terminal lake of the Shiyang River basin and historically the lake level has been relatively high [28]. However, since the 1950s, as a consequence of the diversion of water from the Shiyang River for irrigation and other purposes since the early 20th century, the lake has now dried out. However, during the timescale of interest to this work, many of the small current lakes, e.g. Yema Lake, Qingtu Lake, Dongping Lake, Dongxiao Lake, Xixiao Lake and Baijian Lake, were part of the much larger Zhuye Lake [28]. Among these, Baijian Lake lies on the northwestern Tengger Desert between $104^{\circ} 05^{\prime}-104^{\circ} 11^{\prime} \mathrm{E}$ and $39^{\circ} 03^{\prime}-$ $39^{\circ} 09^{\prime} \mathrm{N}$; the length is $11.8 \mathrm{~km}$ and the width is $3.56 \mathrm{~km}$ [30]. The outside of the lake basin is covered with glutenite, sandstone and mudstone, which were deposited in the Tertiary, and some alluvium or aeolian sand and silt clay, which were deposited in the Quaternary [30].

\subsection{Yabrai Salt Lake}

The Yabrai Salt Lake is a semi-closed basin. It is located in south Alxa Right Banner, between the folded zones of the

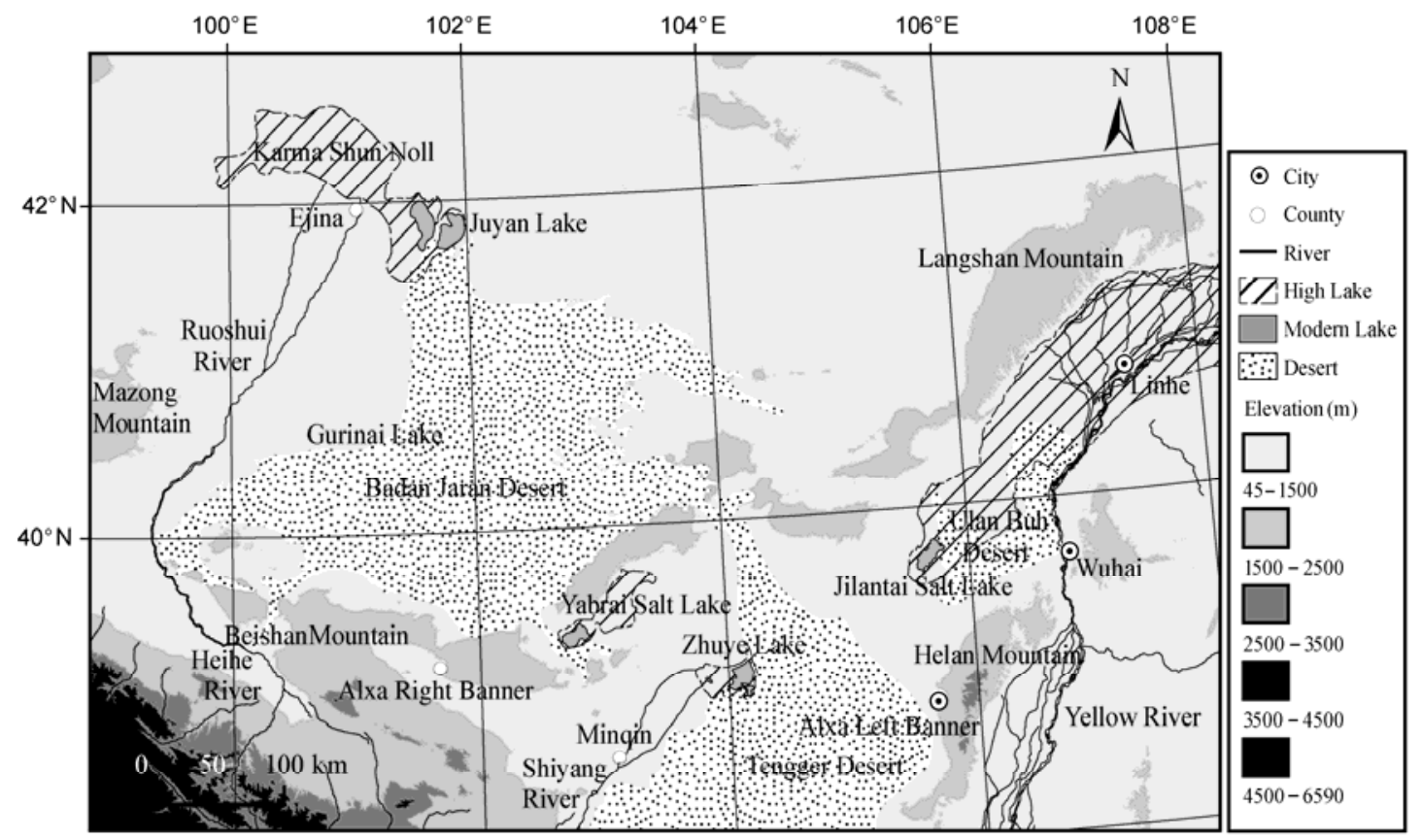

Figure 1 Study area of the Alxa Plateau in northwest China. 
Yabrai and Beida Mountains. There are some salt minerals in the lake sediments, including mirabilite, thenardite, gypsum, etc. The lake basin is a subsidence hollow which is located in the marginal fault basin formed during the Cenozoic. The exposed rocks include some Cenozoic rocks, such as the red glutenite, sand stone and mudstone. There are also some mid-late Pleistocene alluvium and aeolian glutenite, silt, silt clay, which are widely distributed and deposited more than $50 \mathrm{~m}$ in thickness.

\subsection{Juyan Lake}

The Juyan Lake is located in the northwest Alxa Plateau. Historically, it was the terminal lake of the Heihe River [29]. Presently, a certain amount of water is still flowing into the lake basin. The $\leqslant 300 \mathrm{~m}$ thick basin fillers of Quaternary age are of lacustrine origin, with grain-size diameters in the clay and silt fractions, locally interrupted by fluvial and aeolian sand.

\subsection{Jilantai Salt Lake}

The Jilantai Salt Lake is a large modern salt lake in the Jilantai Basin situated in west Inner Mongolia, with a surface elevation of 1017-1023 m ASL. Tectonically, it is a part of the Hetao basin, a Cenozoic fault basin surrounded by the Ordos Plateau, the Helan and Yinshan Mountains. It is also surrounded by the Ulan Buh and Tengger Deserts. Inside the lake basin and the lakefront there are Pleistocene and Holocene lacustrine sediments, aeolian sediments and alluvial deposits, such as glutenite, sand, silt, mud and mirabilite. The shore and beach are formed of these sediments and deposits.

\section{Field methodologies}

Using the geomorphology and sedimentology of the lake, height of the scarp of the trailing edge terrace, or the height of the highest terrace, a consistent picture of lake level and time of formation was assembled. The majority of modern lakes on the Alxa Plateau are closed salt lakes, and using geomorphological evidence of the extent of the paleo-lakes (e.g. vestigial sand gravel and sand clay left after the lakes retreated, filled lake plains, sandy and gravelly shorelines and terraces), the areas and levels of these paleo-lakes can be reconstructed. These same vestigial geomorphological features are also found in the desert around dry desert lakes (Figure 2). Sandy and gravelly shorelines formed when the lake surface was relatively stable while in retreat, so a series of shorelines like concentric circles or several parallel lines is formed. In some large dry desert lakes, shorelines can be easily verified by Remote Sensing Images [31]. Some old shorelines were altered by the fluctuating lake level, but usually the highest shoreline of the highest lake level period

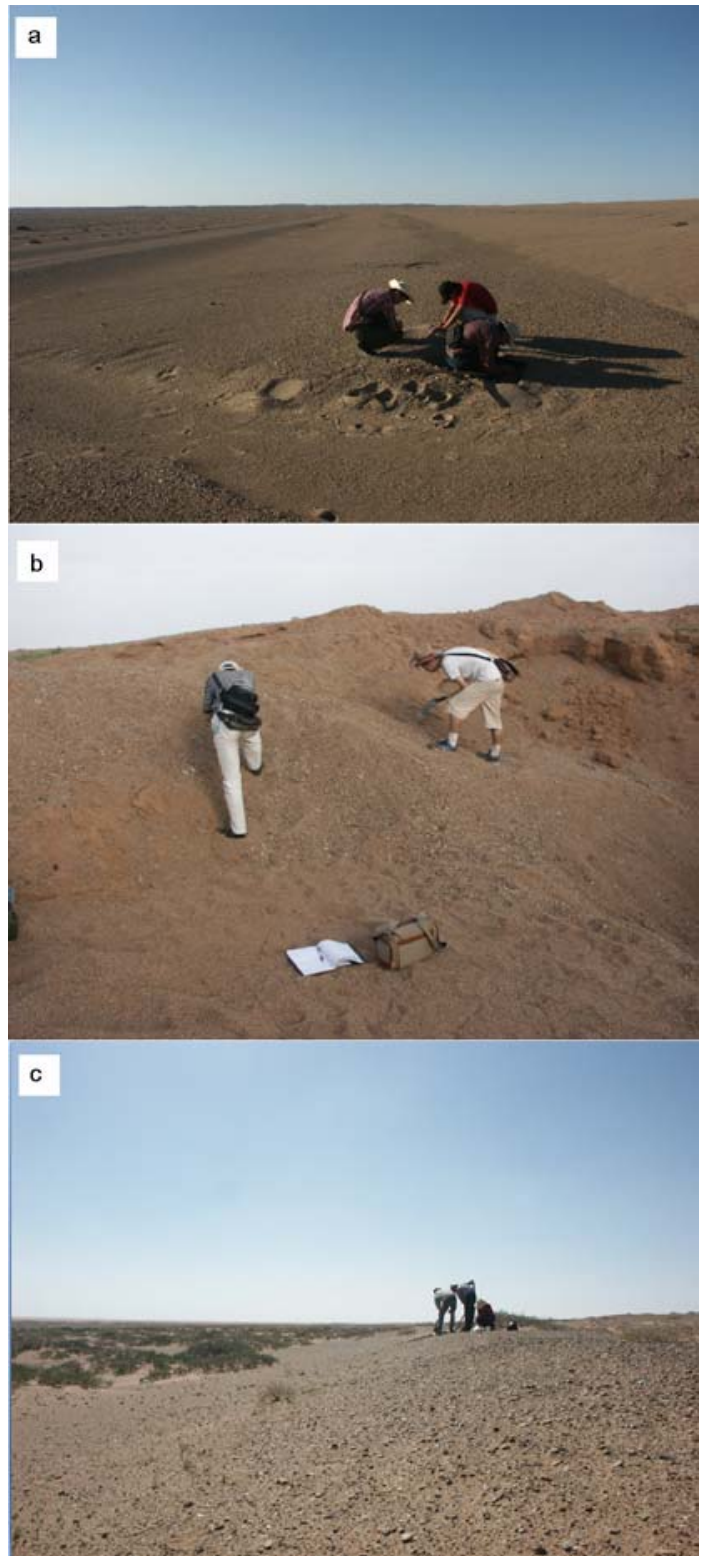

Figure 2 The lake shorelines and terraces in the Alxa Plateau. a, The first shoreline at Juyan Lake (JB1), with an elevation of $932 \mathrm{~m}$, the bivalves were dated at $29.480 \pm 0.095 \mathrm{ka} \mathrm{BP}$ by $\mathrm{AMS}{ }^{14} \mathrm{C}$; b the highest terrace in Jilantai Lake, with an elevation of $1066 \mathrm{~m}$, the bivalves were dated at 37.030 \pm 0.160 ka BP by AMS ${ }^{14} \mathrm{C}$; c, the first shoreline at Zhuye Lake (ZB1), with an elevation of $1311-1313 \mathrm{~m}$, the bivalves were dated at $34-23 \mathrm{ka} \mathrm{BP}$ by ${ }^{14} \mathrm{C}$.

is preserved. These are used to accurately reconstruct paleolake areas.

We examined the vestigial evidence of the extent of paleo-lakes, and using reasoning outline above, reconstructed the paleo-lakes. GPS co-ordinates measured on-site, and the paleo-lakes plotted onto 1:50000 scale topographic maps.

\section{Results}

The results are presented based at each site, first for lake 
levels, then for chronology. Approximate lake areas (Table 1) estimated using GPS from our fieldwork and plotting onto 1:50000 scale topographic maps are shown in Table 1.

Previous work has identified many shorelines and terraces in the Alxa Plateau, such as those at Zhuye Lake [4-6], Juyan Lake [32,33] and Jilantai Lake [1,2]. This work has confirmed and enhanced the previously published paleolake shorelines and terraces (Figure 2).

\subsection{Zhuye Lake}

There are at least five well-preserved shorelines and one terrace in the lake, which have been reported by Zhang et al. [4,6] and Pachur et al. [5]. During our field reconnaissance, a total of nine shorelines and one terrace were found. The shapes of the shorelines are similar but the gradient toward the lake is apparently smaller on one side than the other. The vertical profiles are divided into two parts; the upper part comprises lakeshore facies, which is thick gravel with lots of shells and bivalves, and an oblique layer can be clearly observed; the lower part is lake facies, which are lacustrine sediments such as silt and clay with no oblique layer. The terrace is $80-90 \mathrm{~m}$ wide, and the relative height of the trailing edge terrace is $2-3 \mathrm{~m}$. The leading edge terrace is about $1.5 \mathrm{~m}$. The gradient of the terrace is $7.5^{\circ}$. There are many angular rocks with diameters of $1.5-4.5 \mathrm{~cm}$ on the terrace. Bivalves are found on the terrace sporadically along with some fossil snails, which sometimes occur as distinctive layers of about $5 \mathrm{~cm}$ thickness.

The highest altitude of trailing edge terrace represents the highest lake level, which is $1315-1317 \mathrm{~m}$ above sea level. The altitudes of the shorelines are 1310-1313 m, 13051307, 1302, 1301, 1300, 1298, 1296, 1295 and $1294 \mathrm{~m}$
(Figure 2c).

The highest terrace and various shorelines in the Zhuye Lake can be generalized in Table 2. There are some cone snails and flat spirals at a depth of $1.5 \mathrm{~m}$ in the terrace, and the AMS ${ }^{14} \mathrm{C}$ ages are of these are $37.015 \pm 0.215 \mathrm{ka} \mathrm{BP}$. The first shoreline (Figure 2c: ZB1, 1310-1313 m) is rich in fossil bivalves, which were dated at $34.677 \pm 0.276 \mathrm{ka} \mathrm{BP}$, $32.415 \pm 0.26 \mathrm{ka} \mathrm{BP}, 30.535 \pm 0.25 \mathrm{ka}$ BP and 23.215 \pm 0.197 ka BP by conventional ${ }^{14} \mathrm{C}$. The dating results are presented in Table 3, and are consistent with other work [6] and high lake levels at (32.6-22.2 ka BP). This provides further evidence to support high lake levels occurring in MIS 3c.

\subsection{Yabrai Salt Lake}

In Baiquanzi $\left(39^{\circ} 24^{\prime} 04^{\prime \prime} \mathrm{N}, 102^{\circ} 41^{\prime} 49^{\prime \prime} \mathrm{E}\right)$, northwest of the Yabrai Salt Lake, clay sediments with obvious Shore lake facies are distributed, and the altitude is about $1263 \mathrm{~m}$ ASL. South of the Yabrai salt flat, a similar terrace with obvious scarp was discovered. Due to the effects of aeolian erosion on the original landform, visually it is difficult to be sure whether it is actually the terrace. After excavating a profile through it $\left(39^{\circ} 21^{\prime} 58^{\prime \prime} \mathrm{N}, 102^{\circ} 49^{\prime} 25^{\prime \prime} \mathrm{E}\right)$, an obvious lake sediment layer is present at the base (Figure 3), which suggests that at that time, the Yabrai Salt Lake had reached an altitude of at least $1260 \mathrm{~m}$.

Profile data from the Yabulai Salt Lake in the western part of the Tengger Desert revealed that the late Pleistocene deposits are more than $4 \mathrm{~m}$ thick and dominated by lacustrine sediments (Figure 3). In Baiquanzi, northwest of the Lake $\left(39^{\circ} 24^{\prime} 04^{\prime \prime} \mathrm{N}, 102^{\circ} 41^{\prime} 49^{\prime \prime} \mathrm{E}\right)$, samples of clay sediments which were obviously shore lake facies were dated at $21.559 \pm 0.227 \mathrm{ka}$ BP. From another location, $\left(39^{\circ} 21^{\prime} 58^{\prime \prime} \mathrm{N}\right.$,

Table 1 The altitudes and areas of the high lake levels during the late Quaternary in Alxa Plateau

\begin{tabular}{ccc}
\hline Lake & Proof of high lake levels & Altitude $(\mathrm{m})$ \\
\hline Zhuye Lake & terrace, shorelines and lake sediments & $1315-1317$ \\
Yabulai Salt Lake & lake sediments & 1260 \\
Juyan Lake & terrace, shorelines and sediments & $931-933$ \\
Jilantai Salt Lake & terrace, shorelines and sediments & 1680 \\
\hline
\end{tabular}

Table 2 The altitudes and the dating of the shorelines at Zhuye Lake

\begin{tabular}{|c|c|c|c|c|c|}
\hline Terraces and shorelines & Latitude (N) & Longitude (E) & Altitude (m) & Age (ka BP) & ${ }^{14} \mathrm{C}$ dating material \\
\hline $\mathrm{T}$ & $39^{\circ} 09^{\prime} 55^{\prime \prime}$ & $104^{\circ} 09^{\prime} 41^{\prime \prime}$ & 1316 & 37 & cone snail \\
\hline ZB1 & $39^{\circ} 08^{\prime} 46^{\prime \prime}$ & $104^{\circ} 07^{\prime} 57^{\prime \prime}$ & $1310-1313$ & $34-23$ & bivalves \\
\hline ZB3 & $39^{\circ} 08^{\prime} 44^{\prime \prime}$ & $104^{\circ} 08^{\prime} 07^{\prime \prime}$ & 1302 & 4.9 & cone snail \\
\hline ZB4 & $39^{\circ} 08^{\prime} 42^{\prime \prime}$ & $104^{\circ} 08^{\prime} 10^{\prime \prime}$ & 1301 & - & \\
\hline ZB5 & $39^{\circ} 08^{\prime} 35^{\prime \prime}$ & $104^{\circ} 08^{\prime} 13^{\prime \prime}$ & 1300 & 4.0 & cone snail \\
\hline ZB6 & $39^{\circ} 08^{\prime} 37^{\prime \prime}$ & $104^{\circ} 08^{\prime} 15^{\prime \prime}$ & 1298 & - & \\
\hline ZB7 & $39^{\circ} 08^{\prime} 34^{\prime \prime}$ & $104^{\circ} 08^{\prime} 22^{\prime \prime}$ & 1296 & 1.5 & plant fragment \\
\hline ZB8 & $39^{\circ} 08^{\prime} 33^{\prime \prime}$ & $104^{\circ} 08^{\prime} 25^{\prime \prime}$ & 1295 & - & \\
\hline ZB9 & $39^{\circ} 08^{\prime} 32^{\prime \prime}$ & $104^{\circ} 08^{\prime} 26^{\prime \prime}$ & 1294 & - & \\
\hline
\end{tabular}




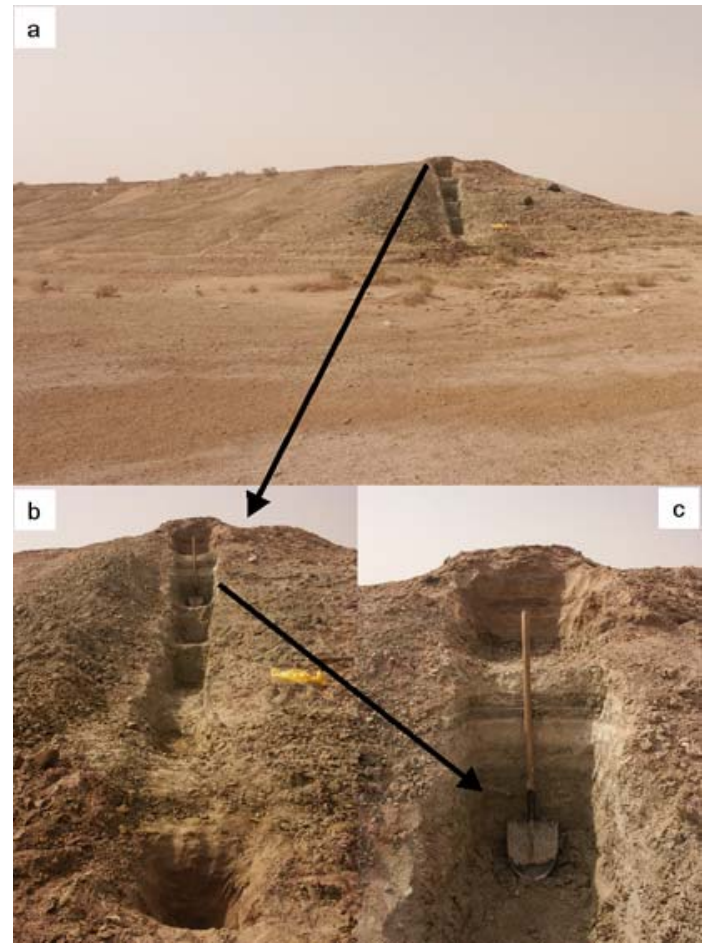

Figure 3 The proof of lake sediment in Yabrai Salt Lake. a, geomorphology of the profile; b, lake sediment in the profile; $c$, the depositional feature in the upper profile.

$\left.102^{\circ} 49^{\prime} 25^{\prime \prime} \mathrm{E}\right)$ of the similar terrace, in the profile we collected the mud samples at the depth of $3.55 \mathrm{~m}$ which were dated at $29.074 \pm 0.212 \mathrm{ka}$ BP by conventional ${ }^{14} \mathrm{C}$ (Figure 4). Though not the highest lake level, the ${ }^{14} \mathrm{C}$ ages in the layer are sufficient to prove that the lacustrine sediments were deposited during MIS 3c.

\subsection{Juyan Lake}

Hoerner and Chen [32] reported 12 shorelines which were formed by lake water in Gaxun Nur (part of Juyan Lake). Among these, seven shorelines were confirmed in geomorphology and the highest of these is $26 \mathrm{~m}$ above the Gaxun Nur surface. Mischke et al. [33] found that there were six shorelines in northwest Swan Lake (part of Juyan Lake), and the highest altitude of the lake shoreline was about 930 m ASL. During field work in 2003, 2006 and 2010, more than 10 lake shorelines in total were found by the authors at east Swan Lake, and the altitude of the highest shoreline (JB1) is between 931 and $933 \mathrm{~m} \mathrm{ASL}$ (Figure 2a). It consists of sediments such as small gravel, sand and silt. JB1 is about $30 \mathrm{~m}$ wide, with four to five small shorelines. With the exception of JB1, all of the shorelines are lower than $930 \mathrm{~m}$ ASL.

The highest shoreline in Juyan Lake is about 931-933 m ASL. We collected bivalves from the shoreline $\left(42^{\circ} 0^{\prime} 13^{\prime \prime} \mathrm{N}\right.$, $\left.101^{\circ} 40^{\prime} 19^{\prime \prime} \mathrm{E}\right)$ and used them for AMS ${ }^{14} \mathrm{C}$. They were dated at $29.480 \pm 0.095 \mathrm{ka} \mathrm{BP}$ (Table 3 ). On the lake erosion terrace, with an elevation of about $930 \mathrm{~m}$, the bivalves were

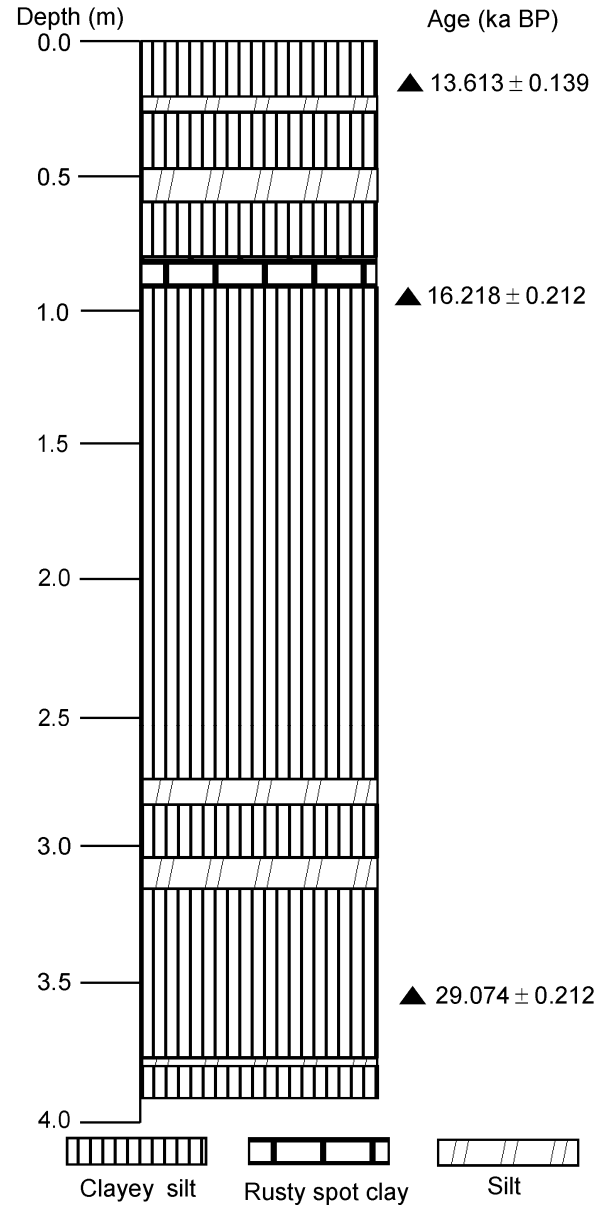

Figure 4 Lithology and dates at Yabulai Salt Lake.

dated at $27.303 \pm 0.218 \mathrm{ka} \mathrm{BP}$. The second shoreline (JB2), with an elevation of $929 \mathrm{~m}$, is $48 \mathrm{~m}$ in width, and can be divided into three parts: $\mathrm{JB}_{21}, \mathrm{JB}_{22}$ and $\mathrm{JB}_{23}$. $\mathrm{JB} 2$ was not dated due to a lack of datable matter. In north Swan Lake, the shoreline occurs at $926 \mathrm{~m}$ elevation, which is the same as that of the eighth shoreline (JB8). The bivalves that we collected on the surface of the shoreline $\left(42^{\circ} 01^{\prime} 15^{\prime \prime} \mathrm{N}\right.$, $\left.101^{\circ} 33^{\prime} 22^{\prime \prime} \mathrm{E}\right)$ were dated at $21.395 \pm 0.218 \mathrm{ka}$ BP. It can be inferred that the shorelines (JB1-JB8) were the vestigial evidence of the high lake levels during MIS 3.

\subsection{Jilantai Salt Lake}

Around the Jilantai Salt Lake, and below 1060 m, shorelines occur at the 1060, 1050, 1044, and $1035 \mathrm{~m}$, and these are higher than the playa surface by $37,27,21$ and $12 \mathrm{~m}$, respectively [2]. At least four more were discovered during Nov. 2003-Aug. 2005 as part of this work. The terrace, with a surface elevation of $1066 \mathrm{~m}$ ASL, consists of sand gravel, with some rocks or gray lacustrine deposits exposed on the front edge. The two highest shorelines are at elevations of 1054 and $1056 \mathrm{~m} \mathrm{ASL}$ and a width of $28-60 \mathrm{~m}$. The trend is $220^{\circ}-230^{\circ}$, with $4^{\circ}$ gradients towards the lake and a $4.5^{\circ}$ gradient on the other side. At elevation of $1051 \mathrm{~m} \mathrm{ASL}$, the 
Table 3 Geomorphology and ${ }^{14} \mathrm{C}$ ages for high lake levels

\begin{tabular}{|c|c|c|c|c|c|c|}
\hline \multirow{2}{*}{ Lake } & \multirow{2}{*}{ Geomorphic type } & \multicolumn{2}{|c|}{ Coordinates of the sample point } & \multirow{2}{*}{ Altitude (m) } & \multirow{2}{*}{ Dating material } & \multirow{2}{*}{${ }^{14} \mathrm{C}$ data (ka BP) } \\
\hline & & Latitude $(\mathrm{N})$ & Longitude (E) & & & \\
\hline Zhuye Lake & lake terrace & $39^{\circ} 09^{\prime} 55^{\prime \prime}$ & $104^{\circ} 09^{\prime} 41^{\prime \prime}$ & 1316 & cone snail & $37.015 \pm 0.215$ (AMS) \\
\hline Zhuye Lake & lake shoreline & $39^{\circ} 06^{\prime} 52^{\prime \prime}$ & $103^{\circ} 58^{\prime} 07^{\prime \prime}$ & 1311 & bivalves & $30.535 \pm 0.250$ \\
\hline Zhuye Lake & lake shoreline & $39^{\circ} 06^{\prime} 54^{\prime \prime}$ & $103^{\circ} 58^{\prime} 06^{\prime \prime}$ & 1311 & bivalves & $32.415 \pm 0.260$ \\
\hline Zhuye Lake & lake shoreline & $39^{\circ} 06^{\prime} 54^{\prime \prime}$ & $103^{\circ} 58^{\prime} 06^{\prime \prime}$ & 1311 & bivalves & $34.677 \pm 0.276$ \\
\hline Zhuye Lake & lake shoreline & $39^{\circ} 09^{\prime} 38^{\prime \prime}$ & $104^{\circ} 10^{\prime} 27^{\prime \prime}$ & 1310 & bivalves & $23.215 \pm 0.197$ \\
\hline Yabulai Salt Lake & lake shore plain & $39^{\circ} 24^{\prime} 04^{\prime \prime}$ & $102^{\circ} 41^{\prime} 49^{\prime \prime}$ & 1263 & clay sediments in the layer & $21.559 \pm 0.227$ \\
\hline Yabulai Salt Lake & lake terrace & $39^{\circ} 21^{\prime} 58^{\prime \prime}$ & $102^{\circ} 49^{\prime} 25^{\prime \prime}$ & 1229 & lake sediments in the layer & $29.074 \pm 0.212$ \\
\hline Juyan Lake & lake shoreline & $42^{\circ} 00^{\prime} 13^{\prime \prime}$ & $101^{\circ} 40^{\prime} 19^{\prime \prime}$ & 932 & bivalves & $29.480 \pm 0.095(\mathrm{AMS})$ \\
\hline Juyan Lake & lake terrace & $41^{\circ} 59^{\prime} 03^{\prime \prime}$ & $101^{\circ} 40^{\prime} 22^{\prime \prime}$ & 930 & bivalves & $27.303 \pm 0.218$ (AMS) \\
\hline Juyan Lake & lake shoreline & $42^{\circ} 01^{\prime} 15^{\prime \prime}$ & $101^{\circ} 33^{\prime} 22^{\prime \prime}$ & 926 & bivalves & $21.395 \pm 0.187$ \\
\hline Jilantai Salt Lake & lake shore plain & $39^{\circ} 46^{\prime} 58^{\prime \prime}$ & $105^{\circ} 38^{\prime} 12^{\prime \prime}$ & 1054 & bivalves & $37.030 \pm 0.160$ (AMS) \\
\hline Jilantai Salt Lake & lake shoreline & $39^{\circ} 46^{\prime} 54^{\prime \prime}$ & $105^{\circ} 38^{\prime} 22^{\prime \prime}$ & 1056 & bivalves & $32.915 \pm 0.115$ (AMS) \\
\hline Jilantai Salt Lake & lake shoreline & $39^{\circ} 46^{\prime} 43^{\prime \prime}$ & $105^{\circ} 39^{\prime} 14^{\prime \prime}$ & 1051 & bivalves & $24.070 \pm 0.065$ (AMS) \\
\hline Jilantai Salt Lake & lake shore plain & $39^{\circ} 33^{\prime} 17^{\prime \prime}$ & $105^{\circ} 35^{\prime} 58^{\prime \prime}$ & 1058 & bivalves & $23.000 \pm 0.065$ (AMS) \\
\hline
\end{tabular}

second shoreline is made up of the mid-thin gravels and coarse sand. The next shoreline has an elevation of $1046 \mathrm{~m}$, and is made up of gray lacustrine sediments. This shoreline contains a lot of cone snails (AMS ${ }^{14} \mathrm{C}$ results were $9.495 \pm$ $0.089 \mathrm{ka} \mathrm{BP}$ and $9.738 \pm 0.087 \mathrm{ka} \mathrm{BP}$ ), less bivalves and flat spirals. Nitraria is spread in sandpiles from this elevation to $1025 \mathrm{~m}$. At elevation of $1025 \mathrm{~m}$, salt marsh plains start to replace sandpiles.

Authors collected bivalves on the beach $\left(39^{\circ} 46^{\prime} 58^{\prime \prime} \mathrm{N}\right.$, $\left.105^{\circ} 38^{\prime} 12^{\prime \prime} \mathrm{E}\right)$ which lies between the highest terrace (1066

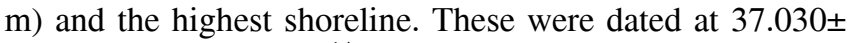
$0.160 \mathrm{ka}$ BP by AMS ${ }^{14} \mathrm{C}$ (Table 3). On the first shoreline $(1056 \mathrm{~m})$, bivalves were dated at $32.915 \pm 0.115 \mathrm{ka} \mathrm{BP}$, and on the second shoreline $(1051 \mathrm{~m})$, bivalves collected from the sample point $\left(39^{\circ} 46^{\prime} 43^{\prime \prime} \mathrm{N}, 105^{\circ} 39^{\prime} 14^{\prime \prime} \mathrm{E}\right)$ were dated at $24.070 \pm 0.065 \mathrm{ka}$ BP. The third shoreline $(1046 \mathrm{~m})$ comprised of angular gravels and was not dated duo to the lack of datable matter. But on the beach $(1030 \mathrm{~m})$, bivalves were collected and dated at $9.738 \pm 0.087 \mathrm{ka}$ BP. Bivalves collected from the sample point $\left(39^{\circ} 33^{\prime} 17^{\prime \prime} \mathrm{N}, 105^{\circ} 35^{\prime} 58^{\prime \prime} \mathrm{E}\right)$ southwest of Jilantai Salt Lake, elevation $1058 \mathrm{~m}$ gave AMS ${ }^{14} \mathrm{C}$ ages of $23.000 \pm 0.065 \mathrm{ka} \mathrm{BP}$. Hence, it is concluded that the Jilantai Salt Lake had high lake levels during MIS 3c.

\section{Discussion}

Using ${ }^{14} \mathrm{C}$ data from a number of lakes, some have proposed that high lake levels on the Alxa Plateau occurred late in MIS $3[4,6]$. Others, on the other hand, using OSL dating (from just one lake, the Jilantai Salt Lake), have proposed that the maximum high stands in this region probably date from an earlier period [2]. The two techniques give different chronological results $[2,4,6]$. Zhang et al. [34] has pointed out that reliable ${ }^{14} \mathrm{C}$ results are credible with reliable samples, although generating reliable high-resolution chronologies per se is difficult. Long et al. [35] have a view that OSL dating has considerable potential for improving the dating of Holocene lake sediments in the arid land of northern China, especially in those cases where there is a significant "hard water" effect. Although the "hard water" effect of 2500 years is present in ${ }^{14} \mathrm{C}$ results of the Huahai Lake [36], it is thought that this affects the ${ }^{14} \mathrm{C}$ results from Zhuye Lake [35,37] much less. If this is the case, it is necessary to discuss the chronology of high stands of lake levels by comparing different dating methods.

Other ${ }^{14} \mathrm{C}$ work has shown that during the late Pleistocene, paleo-lakes covered an area of more than $20000 \mathrm{~km}^{2}$. These paleo-lakes started to develop between 42 and $37 \mathrm{ka}$ $\mathrm{BP}$, and the highest lake levels formed between 35 and 22 $\mathrm{ka} \mathrm{BP}$ - these have been called "the Greatest lakes in Tengger" [4,6]. In Zhuye Lake, two 7-m depth profiles were excavated and the revealed layers yielded a wealth of ${ }^{14} \mathrm{C}$ data, and good chronological evidence [35,37-41]. The ${ }^{14} \mathrm{C}$ dating of shells on lake shorelines from our work is consistent with that in those studies, and that of Zhang et al. [4]. In short, the geomorphological evidence in this work and the sedimentological evidence published by Zhang et al. [4] both indicate that at Zhuye Lake, Juyan Lake, Jilantai Salt Lake and Yabulai Salt Lake, the "Greatest Lakes" with high lake levels existed in MIS 3, between 37 and $21 \mathrm{ka} \mathrm{BP.}$ Furthermore, the highest lake levels occurred between 37 and $29 \mathrm{ka}$ BP (Table 3), and the next highest lake levels occurred between 24 and $21 \mathrm{ka}$ BP. These results taken together indicate that the lake levels were not absolutely constant during period of "the Greatest Lakes", but they fluctuated on different time scales.

OSL chronology for high lake levels is only from the Jilantai Salt Lake [2]. When the layer depth changed 
corresponding highest lake levels, all of the OSL results above $1068 \mathrm{~m}$ are older than $56 \mathrm{ka}$. Moreover, some OSL results above $1080 \mathrm{~m}$ are between 80 and $95 \mathrm{ka}$. In addition, four reported shorelines (1060, 1050, 1044 and $1035 \mathrm{~m}$ ) indicate that the paleo-lake levels fluctuated from 50-60 ka to the Holocene. The OSL ages that have been reported in the "Jilantai-Hetao paleo-lake" have a large span in elevation (almost $100 \mathrm{~m}$ ) during the period 40 to $100 \mathrm{ka} \mathrm{[21].}$ These large variations indicate that the OSL ages may have multiple interpretations, and hence their environmental significance is ambiguous. There is also some doubt as to the veracity of the OSL ages. Nie et al. [42] indicate that (lake) fauna existed in the Hetao basin between 40 and $22 \mathrm{ka} \mathrm{BP}$. This indicates that a paleo-lake existed between 40 and 22 ka BP. The ${ }^{14} \mathrm{C}$ ages of these lake fossils [39] are similar to ${ }^{14} \mathrm{C}$ ages found in our work, and indicates that lakes were widely formed late in MIS 3.

OSL results from Qinghai Lake also showed that the high lake levels occurred earlier indicated by ${ }^{14} \mathrm{C}$ results. In the North and South Lake, Madsen et al. [10] considered that lagoonal deposits at $3240 \mathrm{~m}$ ASL occurred between 94 and $102 \mathrm{ka}$, and lacustrine deposits (on the southwest shore) at 3205-3210 m ASL occurred at $95 \mathrm{ka}$. This was in the context of an absence of lacustrine deposits dating between 95 and $25 \mathrm{ka}$ in the same locale, and an OSL deposit date of $38.8 \mathrm{ka}$ on a sample that was from alluvial (not lacustrine) deposits [10]. They argued that maximum high-stands of 20-66 m above modern probably date to MIS 5, and MIS 3 high stands may have been at or below postglacial highs [10]. Porter et al. [43] also reported thermoluminescence (TL) ages of 44.5 and $45.5 \mathrm{ka}$ from loess lenses within the alluvial bajada gravels along the southern margin of the lake at an elevation of 3315 to $3220 \mathrm{~m}$, which implies the lake level is low. But recently, Liu et al. [18] indicated that the lacustrine deposits along the East Lake were dated at $40 \pm 5$ ka from the OSL work, and the lake was at a high level, which means that high lake levels existed in MIS 3c.

Clearly, there is a problem here. The OSL dates in MIS 3 of Madsen et al. [10] and the ${ }^{14} \mathrm{C}$ dates in MIS 3 of others $[44,45]$, are from the alluvial, not the lacustrine deposits [10]. So from both a geomorphological and sedimentological perspective, there are issues around the chronology of the high stands of lake levels of Qinghai Lake. Furthermore, there are questions about whether the profile from the southern Qinghai Lake which underlies this work is representative, or whether it is influenced by tectogenesis [21]. Moreover, even if the alluvial deposits reported by Madsen et al. [10] are confirmed by subsequent research, the pre- existing drill hole clearly shows that the lake level rose and the depth of the lake increased between 34 and $24 \mathrm{ka}$ BP [45]. Hence, it cannot conclude that the MIS 3 high stands are uncertain. On the other hand, if the conclusions about the alluvial deposits in Qinghai Lake are incorrect, it will indicate that the lake had experienced two high lake levels, one in MIS 5 and the other in MIS 3.

Although OSL has been widely applied to dating lakeshore sediments in recent years [46-48], it has a very different basis to that of the ${ }^{14} \mathrm{C}$ method. Whereas ${ }^{14} \mathrm{C}$ utilizes the decay of the ${ }^{14} \mathrm{C}$ isotope from the time of death of a once-living organism to derive an age, OSL uses optical techniques to measure the last time that the object in question was exposed to sunlight (actually the bleaching of quartz grains). So although these two methods both yield an "age", they are potentially measuring different things. To complicate matters slightly, the ${ }^{14} \mathrm{C}$ results from the shells on lake shorelines can be affected by the "hard water effect", this gives apparent ages that may be older than their real ages (NB not younger).

If shorelines dated to MIS 5 have been preserved, OSL dating results would reflect their formation ages accurately; however, it would not be possible to use ${ }^{14} \mathrm{C}$ methodology (MIS 5 is more than $40 \mathrm{ka} \mathrm{BP}$ ). However, if a shoreline which dates back to MIS 5 is covered by a more recent shoreline or lake sediment (e.g. from MIS 3), or two periods of the shorelines have similar altitudes, the situation becomes complex. Therefore, if the shoreline altitudes in MIS 3 were very similar or the same as those formed in MIS 5, the optical signals of quartz sands formed in MIS 5 would not be well-bleached. The OSL will date the whole shoreline as older, MIS 5. Meanwhile, on the lake shorelines, the preserved shells whose formation ages are MIS 3 can be dated back to MIS 3 by ${ }^{14} \mathrm{C}$. This is likely to cause big differences in the dating results of the two methods, and is likely the situation here. This also indicates that the same shoreline formed in different periods, hence lake levels were very similar in the two periods.

The different principles of OSL and ${ }^{14} \mathrm{C}$ may explain the different dating results in Jilantai Salt Lake. That is to say, lake levels were likely to reach $1060 \mathrm{~m}$ ASL between 50 to $60 \mathrm{ka}$, as well as at $37 \mathrm{ka} \mathrm{BP}$. That is, during two different periods, the shoreline formed in the same place. Furthermore, the lake levels reached a height greater than $1080 \mathrm{~m}$ ASL during MIS 3. Table 4 compares results from both OSL and ${ }^{14} \mathrm{C}$ techniques from three locations.

At Jinsanjiao in Jilantai Salt Lake $\left(39^{\circ} 29^{\prime} 55^{\prime \prime} \mathrm{N}\right.$, $\left.105^{\circ} 35^{\prime} 21^{\prime \prime} \mathrm{E}\right)$, with an elevation $>1080 \mathrm{~m}$ ASL, the OSL

Table 4 A comparison of OSL and ${ }^{14} \mathrm{C}$ results in Jilantai Salt Lake (dating results are cited from [2])

\begin{tabular}{ccccc}
\hline Sampling site & Location & Elevation/depth $(\mathrm{m})$ & Strata & Material/method \\
\hline Jinsanjiao & $39^{\circ} 29^{\prime} 55^{\prime \prime} \mathrm{N}, 105^{\circ} 35^{\prime} 21^{\prime \prime} \mathrm{E}$ & $1083 / 0.8$ & lacustrine silt & quartz/OSL \\
$60 \mathrm{~km}$ Wuyuan County & $41^{\circ} 07^{\prime} 28^{\prime \prime} \mathrm{N}, 108^{\circ} 56^{\prime} 21^{\prime \prime} \mathrm{E}$ & $1090 / 6.0$ & littoral gravels & quartz/OSL \\
Wuda brick factory & $39^{\circ} 32^{\prime} 52^{\prime \prime} \mathrm{N}, 106^{\circ} 46^{\prime} 28^{\prime \prime} \mathrm{E}$ & $1093 / 7.0$ & lenticula in delta profile & charcoal and plant remains/ ${ }^{14} \mathrm{C}(41.45 \pm 0.47)$ cal ka BP \\
\hline
\end{tabular}


dating results are obvious different from the ${ }^{14} \mathrm{C}$ results obtained from the Wuda brick factory $\left(39^{\circ} 32^{\prime} 52^{\prime \prime} \mathrm{N}\right.$, $\left.106^{\circ} 46^{\prime} 28^{\prime \prime} \mathrm{E}\right)$ which is at a similar elevation. The uncorrected ${ }^{14} \mathrm{C}$ is $35.690 \pm 0.320 \mathrm{ka} \mathrm{BP}$ (Calibrated ${ }^{14} \mathrm{C}$ age is $41.45 \pm 0.47 \mathrm{cal} \mathrm{ka} \mathrm{BP})$. This is consistent with other ${ }^{14} \mathrm{C}$ results [2], which gave the age of the underwater delta to be at least $41 \mathrm{cal} \mathrm{ka} \mathrm{BP}$. Therefore, this confirms that high lake levels in Jinlantai Salt Lake existed during MIS 3 c, and was at or above $1060 \mathrm{~m}$ ASL. Until the inconsistency between the geomorphological and sedimentary evidence is resolved, it remains to be seen whether the Qinghai Lake high stands reached similar attitudes during MIS 5 and MIS 3.

Both MIS 5 and MIS 3 were humid in middle latitudes [49], consistent with the orbital-precession cycles of $\sim 20 \mathrm{ka}$. In Eastern Asia, stalagmite records [50] and loss records [51] indicate that the intensity of the Asian monsoon was strong during MIS 3 and MIS 5, and insolation in the Northern Hemisphere was strong. During such periods, the climate is humid. On Loess Plateau, reconstruction of the climatic history through pollen and phytolith records shows that both MIS 3 and MIS 5 were obviously humid [52-54]. This humidity is also recorded in the Guliya ice core from the Qinghai-Tibet Plateau [55]. Furthermore, during MIS 3, high lake levels formed in the Qaidam Basin [56] and Qinghai-Tibet Plateau [14]. Yang [57] indicates that between 30 and $20 \mathrm{ka} \mathrm{BP}$, the Badain Jaran Desert was humid. That is consistent with the fact that the ancient Egina Lake had high stands and high biomass during between 33.32 and $27.54 \mathrm{ka}$ BP [58,59]. The reconstruction of the MIS 3 environment in the West Loess Plateau by Feng et al. [60] indicated that the extremely wet MIS 3 had a combination of high summer and winter insolation. As more high-resolution climate records from ice-core bubbles and stalagmite isotopes become available, the clear precessional cyclicity of the late Pleistocene summer monsoon becomes more apparent [61]. All of these indicate that the precessional cycles of 20 ka mean that both MIS 3 and MIS 5 had humid conditions suitable for the formation of high stands. Therefore, it is possible or even likely that the lakes have experienced two high lake levels, one in MIS 3 and the other in MIS 5. Pokras et al. [62] showed that large lakes repeatedly appeared in the arid regions of Africa and then dried up, following the $20 \mathrm{ka}$ precession cycles of monsoon precipita tion. Besides, new evidence shows that lake levels higher than those at present in Gahai Lake formed in both late MIS 5 and early MIS 3[19].

Figure 5 shows Reconstructed paleoclimate for the last $120 \mathrm{ka}$. This shows that higher precipitation occurred both early and late in MIS 3. Shi et al. [63] suggests that from 60 to $30 \mathrm{ka}$ ago, between two warm periods with high insolation, there was a cold period with low insolation. It corresponds well to the record in the Guliya ice core during MIS 3 [24]. This event occurred not just locally, but occurred throughout the low latitudes of the Northern hemisphere [64]. The latest evidence from high latitude in the Northern

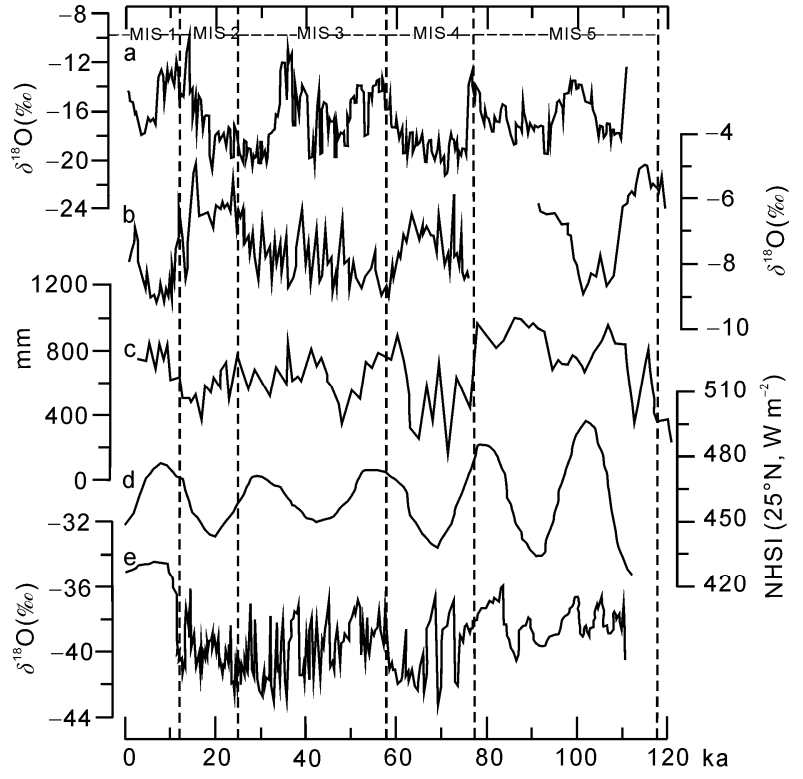

Figure 5 Time-series of reconstructed paleoclimatic data for last $120 \mathrm{ka}$ in the Northern Hemisphere. a, $\delta^{18} \mathrm{O}$ isotopes in Guliya ice core [24]; b, $\delta^{18} \mathrm{O}$ isotopes in South China stalagmite [67]; c, mean annual precipitation by phytolith sequences at the Weinan section [54]; d, insolation in $25^{\circ} \mathrm{N}$ [68]; e, GISP2 ice core $\delta^{18} \mathrm{O}$ [69].

Hemisphere showed that during early MIS 3 mean July air temperatures as high as present-day values [65]. The climate simulations show that about $35 \mathrm{ka} \mathrm{BP}$, the temperature in the mid-low latitudes was increasing and the rain-belt was extending to the north in East Asia [66]. Therefore, the Jilantai Salt lake level could have reached $1060 \mathrm{~m}$ ASL in both early and late MIS 3.

\section{Conclusions}

(1) According to field investigations in Alxa Plateau over the past decade, there are at least 10 well-preserved shorelines at Juyan Lake, at least four shorelines at the northwest Jilantai Salt Lake and at least nine shorelines and one well-preserved terrace at the northeast Zhuye Lake.

(2) With other stratigraphic and chronological evidence, analysis of ${ }^{14} \mathrm{C}$ dating results from bivalves and snails from the lake shorelines shows that the paleo-lakes had high lake levels in MIS $3 \mathrm{c}$ on the Alxa Plateau, and the lake levels fluctuated on different time scales during MIS 3.

(3) The results from OSL and ${ }^{14} \mathrm{C}$ work concerning the timing of high lake levels are not consistent with each other. This work has shown that it is likely that high lake levels existed in both MIS 3 and MIS 5 in the same area.

The authors are grateful to Professors Zhang Hucai and Lai Zhongping for constructive comments and suggestions that helped to improve the manuscript. This work was supported by the National Natural Science Foundation of China (50879033, 41001116 and 40901021), the Specialized Research Fund for the Doctoral Program of Higher Education (SRFD, 20090211110025 and 200807301031) and the Fundamental Research Funds for the Central Universities (lzujbky-2010-221). 
1 Yang L, Chen F, Chun X, et al. The Jilantai Salt Lake shorelines in Northwestern arid China revealed by remote sensing images. J Arid Environ, 2008, 72: 861-866

2 Chen F H, Fan Y X, Chun X, et al. Preliminary research on Megalake Jilantai-Hetao in the arid areas of China during the Late Quaternary. Chinese Sci Bull, 2008, 53: 1725-1739

3 Yang X P, Liu T S, Xiao H L. Evolution of megadunes and lakes in the Badain Jaran Desert, Inner Mongolia, China during the last 31000 years. Quat Int, 2002, 104: 99-112

4 Zhang H C, Peng J L, Ma Y Z, et al. Late Quaternary palaeolake levels in Tengger Desert, NW China. Palaeogeogr Palaeoclimatol Palaeoecol, 2004, 211: 45-58

5 Pachur H J, Wünnemann B, Zhang H C. Lake evolution in the Tengger desert, Northwestern China during last 40000 years. Quat Res, 1995, 44: 171-180

6 Zhang H C, Ma Y Z, Peng J L, et al. Palaeolake and palaeoenvironment between 42 and 18 ka BP in Tengger Desert, NW China. Chinese Sci Bull, 2002, 47: 1946-1956

7 Wünnemann B, Hartman K B. Morphodynamics and paleohydrography of the Gaxun Nur Basin, Inner Mongolia, China. Berlin Stuttgart, 2002, 126: 147-168

8 Rhodes T E, Gasse F, Lin R F, et al. A late Pleistocene-Holocene lacustrine record from Lake Manas, Zunggar (Northern Xinjiang, western China). Palaeogeogr Palaeoclimatol Palaeoecol, 1996, 120: 105-125

9 Han S T, Yuan Y J. The sequence of paleoclimatic variation of Balikun Lake of Xinjiang in the past 35000 years (in Chinese). Acta Geogr Sin, 1990, 45: 350-362

10 Madsen D B, Ma H Z, Rhode D, et al. Age constraints on the late Quaternary evolution of Qinghai Lake, Tibetan Plateau. Quat Res, 2008, 69: 316-325

11 Chen K Z, Bowler J M. Late Pleistocene evolution of salt lakes in the Qaidam Basin, Qinghai Province, China. Palaeogeogr Palaeoclimatol Palaeoecol, 1986, 54: 87-104

12 Zhu D G, Meng X G. Quaternary Environment Evolution in Namtso Lake, Tibet (in Chinese). Beijing: The Geological Publishing House, 2004. 25-93

13 Shi Y F, Yu G, Liu X D, et al. Reconstruction of the 30-40 ka BP enhanced India monsoon climate based on geological record from the Tibetan Plateau. Palaeogeogr Palaeoclimatol Palaeoecol, 2001, 169: 69-83

14 Li B Y. The Last Greatest Lakes on the Xizang (Tibetan) Plateau (in Chinese). Acta Geogr Sin, 2000, 55: 174-182

15 Zhu D G, Meng X G, Zhao X T, et al. Nam Tso Lacustrine Sediments and the Ancient Big Lake in Northern Tibet Plateau (in Chinese). Acta Geosci Sin, 2001, 22: 149-155

16 Zhao X T, Zhu D G, Yan F H, et al. Climatic change and lake-level variation of Nam Co, Xizhang, since the last Interglacial stage (in Chinese). Quat Sci, 2003, 23: 42-51

17 Rhode D, Ma H Z, Madsen D B, et al. Paleoenvironmental and archaeological investigations at Qinghai Lake, western China: Geomorphic and chronometric evidence of lake level history. Quat Int, 2010, 218: 29-44

18 Liu X J, Lai Z P, Fan Q S, et al. Timing for high lake levels of Qinghai Lake in the Qinghai-Tibetan Plateau since the Last Interglaciation based on quartz OSL dating. Quat Geochronol, 2010, 5: 218-222

19 Fan Q S, Lai Z P, Long H, et al. OSL chronology for lacustrine sediments recording high stands of Gahai Lake in Qaidam Basin, northeastern Qinghai-Tibetan Plateau. Quat Geochronol, 2010, 5: 223-227

20 Norin E. Sven Hedin Central Asia Atlas, Memoir on Maps. Vol III. Stockholm: Statens Etnografiska Museum, 1980. 94-110

21 Zhang H C. The Spatial Environments Characteristic in West China during MIS 3 (in Chinese). In: Ding Z L, ed. Integration research about the environment evolution in West China. Beijing: China Meteorological Press, 2010. 107-125

22 Anderson P M, Lozhkin A V. The stage 3 interstadial complex (Karginskii/middle Wisconsinan interval) of Beringia: Variations in palaeoenvironments and implications for paleoclimatic interpretations. Quat Sci Rev, 2001, 20: 93-125
23 Shi Y F, Yu G, Liu X D, et al. Reconstruction of the 30-40 ka BP enhanced India monsoon climate based on geological records from the Tibetan Plateau. Palaeogeogr Palaeoclimatol Palaeoecol, 2001, 169: 69-83

24 Thompson L G, Yao T D, Davis M E, et al. Tropical climate instability: the Last Glacial Cycle from a Qinghai-Tibetan Ice Core. Science, 1997, 276: 1821-1827

25 Penaud A, Eynaud F, Turon J L, et al. Interglacial variability (MIS 5 and MIS 7) and dinoflagellate cyst assemblages in the Bay of Biscay (North Atlantic). Mar Micropaleontol, 2008, 68: 136-155

26 Dumas B, Hoang C T, Raffy J. Record of MIS 5 sea-level highstands based on U/Th dated coral terraces of Haiti. Quat Int, 2006, 145-146: 106-118

27 Wang Y J, Cheng H, Edwards R L, et al. A high-resolution absolute-dated late Pleistocene Monsoon record from Hulu Cave, China. Science, 2001, 294: 2345-2348

28 Feng S W. The evolution of the drainage system of the Minchen Oasis (in Chinese). Acta Geogr Sin, 1963, 29: 241-249

29 Wang S M, Dou H S. Record of Chinese Lakes (in Chinese). Beijing: Science Press, 1998: 322-323

30 Zheng X Y, Zhang M G, Xu C, et al. Record of Chinese Salt Lakes (in Chinese). Beijing: Science Press, 2002. 378

31 Xie Y W, Wang J T. A Study on the changes of Baijian Lake based on TM image and DEM (in Chinese). Remote Sens Tech Appl, 2006, 21: 284-287

32 Hoerner, Chen Z Q. Alternating lake in NW China (in Chinese). Monthly About Local Records, 1935, 8: 23-25

33 Mischke S, Dellske D, Schudack M E. Hydrologic and climatic implications of a multidisciplinary study of the Mid to Late Holocene Lake Eastern Juyanze. Chinese Sci Bull, 2003, 48: 1411-1417

34 Zhang H C, Ming Q Z, Lei G L, et al. Dating on lacustrine deposits in a hyperarid inland basin of NW China. Radiocarbon, 2006, 48: 219226

35 Long H, Lai Z P, Wang N A, et al. A combined luminescence and radiocarbon dating study of Holocene lacustrine sediments from arid northern China. Quat Geochronol, 2011, 6: 1-9

36 Wang N A, Li Z L, Li Y, et al. Younger Dryas event recorded by the mirabilite deposition in Huahai Lake, Hexi Corridor, NW China. Quat Int, 2010, doi:10.1016/j.quaint.2010.11.017

37 Li Y, Wang N A, Cheng H Y, et al. Holocene environmental change in the marginal area of the Asian monsoon: A record from Zhuye Lake, NW China. Boreas, 2009, 38: 349-361

38 Li Y, Wang N A, Morrill C, et al. Environmental change implied by the relationship between pollen assemblages and grain-size in N.W. Chinese lake sediments since the Late Glacial. Rev Palaeobot Palynol, 2009, 154: 54-64

39 Long H, Wang N A, Li Y, et al. Mid-Holocene climate variations from lake records of the east Asian Monsoon margin: A multi-proxy and geomorphological study (in Chinese). Quat Sci, 2007, 27: 371-381

40 Long H, Lai Z P, Wang N A, et al. Holocene climate variations from Zhuyeze terminal lake records in East Asian monsoon margin in arid northern China. Quat Res, 2010, 74: 46-56

41 Li Y, Wang N A, Li Z L, et al. Holocene palynological records and their responses to the controversies of climate system in the Shiyang River drainage basin. Chinese Sci Bull, 2011, 56: 535-546

42 Nie Z S, Li H, Ma B Q. Fossil fauna in the late stage of late Pleistocene in the Hetao Basin, Inner Mongolia (in Chinese). Quat Sci, 2008, 28: 14-25

43 Porter S C, Singhvi A, An Z S, et al. Luminescence age and palaeoenvironmental implications of a Late Pleistocene ground wedge on the northeastern Tibetan plateau. Permafrost Periglacial Pro, 2001, 12: 203-210

44 Wang S M, Shi Y F. Review and discussion on the late Quaternary evolution of Qinghai Lake (in Chinese). J Lake Sci, 1992, 4: 1-9

45 Chen K Z, Bowler J M, Kelts K. Palaeoclimatic evolution within the Qinghai-Xizhang (Tibet) Plateau in the last 40000 years (in Chinese). Quat Sci, 1990, 10: 21-30

46 Nanson G C, Callenb R A, Price D M. Hydroclimatic interpretation of Quaternary shorelines on South Australian playas. Palaeogeogr 
Palaeoclimatol Palaeoecol, 1998, 144: 281-305

47 Mauz B. Late Pleistocene records of littoral processes at the Tyrrhenian Coast (Central Italy): Depositional environments and luminescence chronology. Quat Sci Rev, 1999, 18: 1173-1184

48 Ollerhead J, Huntley D J, Nelson A R, et al. Optical dating of tsunami-laid sand from an Oregon coastal lake. Quat Sci Rev, 2001, 20: 1915-1926

49 Ding Z L, Sun J M, Yu Z W, et al. Paleoclimatic events in Chinese Loess Plateau during the last $130 \mathrm{ka}$ (in Chinese). Chinese Sci Bull, 1998, 43: 567-574

50 Wang Y J, Cheng H, Edwards R L, et al. Millennial- and orbital-scale changes in the East Asian monsoon over the past 224000 years. Nature, 2008, 451: 1090-1093

51 Xiao J L, An Z S, Liu T S, et al. East Asian monsoon variation during the last 130000 Years: Evidence from the Loess Plateau of central China and Lake Biwa of Japan. Quat Sci Rev, 18: 147-157

$52 \mathrm{Li} \mathrm{C} \mathrm{H}$, Tang L Y, Feng Z D, et al. A high-resolution late Pleistocene record of pollen vegetation and climate change from Jingning, NW China. Sci China Ser D-Earth Sci, 2006, 49: 154-162

53 Sun X J, Song C Q, Wang F Y, et al. Vegetation history of the Loess Plateau of China during the last 100000 years based on pollen data (in Chinese). Chinese Sci Bull, 1995, 40: 1222-1224

$54 \mathrm{Lu} \mathrm{H} \mathrm{Y,} \mathrm{Wu} \mathrm{N} \mathrm{Q,} \mathrm{Liu} \mathrm{K} \mathrm{B,} \mathrm{et} \mathrm{al.} \mathrm{Phytoliths} \mathrm{as} \mathrm{quantitative} \mathrm{indicators}$ for the reconstruction of past environmental conditions in China II: palaeoenvironmental reconstruction in the Loess Plateau. Quat Sci Rev, 2007, 26: 759-772

55 Yao T D, Thompson L G, Shi Y F, et al. Climatic change recorded by Guliya ice core since the last interglacial cycle (in Chinese ). Sci China Ser D-Earth Sci, 1997, 27: 447-452

56 Zhang H C, Zhang W X, Chang F Q, et al. Geochemical fractionation of rare earth elements in lacustrine deposits from Qaidam Basin. Sci China Ser D-Earth Sci, 2009, 52: 1703-1713

57 Yang X P. Landscape evolution and precipitation changes in the Badain Jaran Desert during the last 30000 years. Chinese Sci Bull, 2000, 45: 1042-1046

58 Zhang W X, Zhang H C, Lei G L, et al. The $\delta$ Ce- $\sum$ REE instruction on the sedimentary facies (in Chinese). Quat Sci, 2009, 29: 789-796

59 Yang L Q, Zhang H C, Lei Y B, et al. Compositions of the organic matter and carbonate in Xiaohushan section from Ejina basin, western Inner Mongolia, China and their paleoenvironmental significance (in Chinese). Quat Sci, 2009, 29: 256-267

60 Feng Z D, Tang L Y, Ma Y Z, et al. Vegetation variations and associated environmental changes during marine isotope stage 3 in the western part of the Chinese Loess Plateau. Palaeogeogr Palaeoclimatol Palaeoecol, 2007, 246: 278-291

61 Wang P X. Global monsoon in a geological perspective. Chinese Sci Bull, 2009, 54: 1113-1136

62 Pokras E M, Mix A C. Earth's precession cycle and Quaternary climate change in tropical Africa. Nature, 1987, 326: 486-487

63 Shi Y F, Liu X D, Li B Y, et al. A very strong summer monsoon event during $30-40 \mathrm{ka}$ BP in the Qinhai-Xizang (Tibet) Plateau and its relation to precessional cycle. Chinese Sci Bull, 1999, 44: 18511857

64 Shi Y F, Yao T D. MIS 3b (54-44 ka BP) cold period and glacial advance in Middle and Low Latitudes (in Chinese). J Glaciol Geocryol, 2002, 24: 1-9

65 Helmens K F, Risberg J, Jansson K N, et al. Early MIS 3 glacial lake evolution, ice-marginal retreat pattern and climate at Sokli (northeastern Fennoscandia). Quat Sci Rev, 2009, 28: 1880-1894

66 Yu G, Zheng Y Q, Ke X K. 35 ka BP climate simulations in East Asia and probing the mechanisms of climate changes. Chinese Sci Bull, 2005, 50: 58-67

67 Yuan D X, Cheng H, Edwards R L, et al. Timing, duration, and transitions of the Last Interglacial Asian Monsoon. Science, 2004, 304: 575-578

68 Berger A L. Long-term variations of daily insolation and Quaternary climatic changes. J Atmos Sci, 1978, 35: 2362-2367

69 The Greenland Summit Ice Cores CD-ROM. Available from the National Snow and Ice Data Center, University of Colorado at Boulder, and the World Data Center-A for Paleoclimatology, National Geophysical Data Center, Boulder, CO. 1997

Open Access This article is distributed under the terms of the Creative Commons Attribution License which permits any use, distribution, and reproduction in any medium, provided the original author(s) and source are credited. 